\title{
Approximate Entropy as a measure of complexity in sap flow temporal dynamics of two tropical tree species under water deficit
}

\author{
GUSTAVO M. SOUZA, RAFAEL V. RIBEIRO, MAURO G. SANTOS, \\ HENRIQUE L. RIBEIRO and RICARDO F. OLIVEIRA \\ Laboratório de Plantas Cultivadas sob Estresse, Departamento de Ciências Biológicas \\ Escola Superior de Agricultura "Luiz de Queiroz", Universidade de São Paulo, Cx. Postal 9 \\ 13418-900 Piracicaba, SP, Brasil \\ Manuscript received on March 6, 2003; accepted for publication on March 10, 2004; \\ presented by EuRIPEDES MaLAVOLTA
}

\begin{abstract}
Approximate Entropy (ApEn), a model-independent statistics to quantify serial irregularities, was used to evaluate changes in sap flow temporal dynamics of two tropical species of trees subjected to water deficit. Water deficit induced a decrease in sap flow of G. ulmifolia, whereas C. legalis held stable their sap flow levels. Slight increases in time series complexity were observed in both species under drought condition. This study showed that ApEn could be used as a helpful tool to assess slight changes in temporal dynamics of physiological data, and to uncover some patterns of plant physiological responses to environmental stimuli.
\end{abstract}

Key words: Approximate Entropy, complexity, sap flow, time series analysis, tropical ecophysiology, water deficit.

\section{INTRODUCTION}

Time series analysis of plant physiological data has been used to assess the effects of environmental disturbances on plant metabolism (Lüttge and Beck 1992, Krempaský et al. 1993, Shabala et al. 1997, Hütt et al. 2002, Souza et al. 2004). There are, however, several critical statistical issues in the proper application of complexity measures, both theoretically and especially to real data (Pincus 2000, Poon and Barahona 2001).

Therefore, it is proposed to use Approximate Entropy (ApEn) to measure complexity in time se-

Correspondence to: Gustavo M. Souza

Present address: Faculdade de Ciências Agrárias - UNOESTE

Rod. Raposo Tavares, Km 572

19067-175 Presidente Prudente, SP, Brasil

E-mail: gmaia@universiabrasil.net ries of plant physiological data. ApEn is a modelindependent statistic defined in Pincus (1991), with further mathematical properties and representative biological applications (Fleisher et al. 1993, Pincus and Singer 1996, Pincus et al. 1998, Pincus and Singer 1998). ApEn is robust or insensitive to artifacts or outliers: extremely large and small artifacts have small effect on the ApEn calculation, if they occur infrequently. ApEn assigns a non-negative number to a sequence or time-series, with larger values corresponding to greater apparent process randomness or serial irregularity, and smaller values corresponding to more instances of recognizable features or patterns in the data. Two input parameters, a run length $m$ and a tolerance window $r$, must be specified to compute ApEn. This parameter measures 
the logarithmic likelihood that runs of patterns that are close (within $r$ ) for $\mathrm{m}$ contiguous observations remain close (within the same tolerance width $r$ ) on next incremental comparisons. Finally, further technical discussion of mathematical and statistical properties of ApEn, including mesh interplay, relative consistency of $(m, r)$ pair choices, asymptotic normality under general assumptions, and error estimation for general processes can be found elsewhere (Pincus and Huang 1992, Pincus and Goldberger 1994). To develop a more intuitive, physiological understanding of the ApEn definition, a multistep description of its typical algorithmic implementation, with figures, is developed in Pincus and Goldberger (1994).

In this study ApEn was used for the first time to quantify changes in the regularity of temporal dynamics in sap flow of two tropical tree species subjected to water deficit.

\section{MATERIALS AND METHODS}

Seedlings of two tropical species of Brazilian trees of different ecological groups were evaluated. Three 9 month-old seedlings of each species were grown in plastic pots with $10 \mathrm{~kg}$ of an oxisoil, and daily irrigated. Cariniana legalis (Lecythidaceae) and Guazuma ulmifolia (Sterculiaceae) are semideciduous trees typical of semi arid regions, the former species is late successional and the latter one is early successional (Lorenzi 1992).

\section{TREATMENTS}

Seedlings were grown in a greenhouse at the Department of Biological Sciences, ESALQ/USP, Piracicaba, Brazil $\left(22^{\circ} 42^{\prime} \mathrm{S}, 47^{\circ} 38^{\prime} \mathrm{W}, 546 \mathrm{~m}\right.$ of altitude). Plants were subjected to water deficits by withholding irrigation during 72 hours. Water deficits induced in the plants similar leaf water potentials around $-2.55 \mathrm{MPa}$ at noon. Afterwards, the plants were irrigated for 48 hours (recovery) until water potentials reached values similar to the initial condition (control), around-1.32 MPa. The experiment was carried out in January 2003 (summer).

\section{Sap Flow Measurements}

Sap flow rates of three seedlings of each species were measured simultaneously by the heat balance technique devised by Sakuratani (1981), using stem flow gauge models SGA5 and SGA10 (Dynamax Inc., Houston, TX/USA), depending upon stem diameter. Stem segments were slightly sanded and a thin layer of silicone grease (Dow Corning 4, Dow Corning Corp., MI/USA) was applied on the surface to improve contact between the tissue and the heater. The gauges were installed and then covered with three layers of aluminum foil. Data were collected using a datalogger model CR7X (Campbel Sci., Logan, UT/USA). The datalogger was programmed to sample the voltage signals from the gauges every 1 minute. The voltage data were converted to sap flow rate and filtered in a spreadsheet using the formulae and restrictions provided by Van Bavel (1999). After the experimental period, sap flow measurements were halted and leaf area was determined for each plant using an electronic planimeter, model LI3000A (Li-Cor Inc., Lincoln, NE/USA) to calculate sap flow rate per unit leaf area.

\section{Data Analysis}

Approximate entropy (ApEn), as defined in Pincus (1991), was used to quantify serial irregularity. For the study discussed below, ApEn values were calculated with widely established parameter values of $m=2$, and $r=20 \%$ SD (standard deviation) of the sap flow time series. Normalizing $r$ to each timeseries SD in this manner gives ApEn a translationand scale-invariance (Pincus et al. 1993), in that it remains unchanged under uniform process magnification, reduction, or constant shift either higher or lower. Several previous studies that included both theoretical analysis (Pincus 1991, Pincus and Goldberger 1994) and clinical applications (Pincus et al. 1993, Christen et al. 1998, Pincus et al. 1998, Bruhn et al. 2000) have demonstrated that these input parameters produce good statistical reproducibility for ApEn for time series of the lengths considered herein. 
Before ApEn calculation, previous time series analysis using autocorrelation coefficients (data not shown) indicated that the sap flow series were markedly nonstationary. Therefore, ApEn was applied to the first-differenced time series. This transformation, which is a standard statistical method to stationarize time series and it is applicable to a very broad class of models (Chatfield 1989, Williams 1997), was suitable in order to remove the nonstationary factors, according to the correlogram performed after series transformation (data not shown).

Spectral density analyses by Fast Fourier Transform were also performed in order to evaluate possible oscillatory behavior in the sap flow dynamics as observed by Rose et al. (1994) in other plant species.

\section{RESULTS AND DISCUSSION}

Sap flow differences developed during stress period were observed mainly in G. ulmifolia (Figure 1b and c). Under water deficit, daily integrated sap flow decreased $45 \%$ in G. ulmifolia, whereas C. legalis maintained their sap flow levels stable. After the recovery period, however, both species showed similar sap flow reductions (-29\%) in relation to control condition. These sap flow reductions could be partially explained by the milder environment during the measurements in the recovery condition (Figure 1a), demanding lower plant water loss.

Stomatal closure and consequent transpiration decrease are ubiquitous plant responses to water deficit in order to avoid excessive water loss (Nobel 1999). Thus, the presented results suggested that $C$. legalis was not affected by the drought treatment as G. ulmifolia was.

According to the spectral analyses, no single periodic behavior was observed in both species under any tested environmental condition (Figure 2). These analyses indicate that the signals were composed by more than one dominant frequency, mainly under water deficit, although different behaviors can be observed.
Water deficit tended to increase the complexity of the sap flow time series in both species, as indicated by ApEn values (Figure 2), although no significant $(p>0.05)$ differences have been observed. This complexity increase tendency was also observed in the stomatal conductance dynamics of Beta vulgaris and Helianthus annus under water deficit (Souza et al. 2004). Unpublished data from Souza et al. seems to support a hypothesis that environmental perturbations tend to increase the temporal complexity of physiological processes. According to Van Voris et al. (1980) and Souza and Oliveira (2003), complexity and stability are positively correlated. Thus, the complexity increase in the sap flow dynamics could be an adaptive response in order to hold stable the transpiration process. ApEn values tended to decrease after re-hydration, mainly in G. ulmifolia. In this species, the sap flow dynamics at recovery condition showed, significantly $(p<0.05)$, more regularity than at control condition. The changes in ApEn values can be visually verified in the graphs of spectral analyses (Figure 2).

This study showed that ApEn could be used as a helpful tool to assess slight changes in temporal dynamics of physiological data, and to uncover some patterns of plant physiological responses to environmental stimuli.

\section{ACKNOWLEDGMENTS}

The authors are grateful to Dr. Steven M. Pincus for his support in calculation and interpretation of ApEn. G.M.S. and R.V.R. are thankful to FAPESP and M.G.S. to CAPES for the fellowships granted.

\section{RESUMO}

Entropia Aproximada (ApEn), um modelo estatístico independente para quantificar irregularidade em séries temporais, foi utilizada para avaliar alterações na dinâmica temporal do fluxo de seiva em duas espécies arbóreas tropicais submetidas à deficiência hídrica. A deficiência hídrica induziu uma grande redução no fluxo de seiva em G. ulmifolia, enquanto que na espécie $C$. legalis manteve-se estável. A complexidade das séries temporais foi 


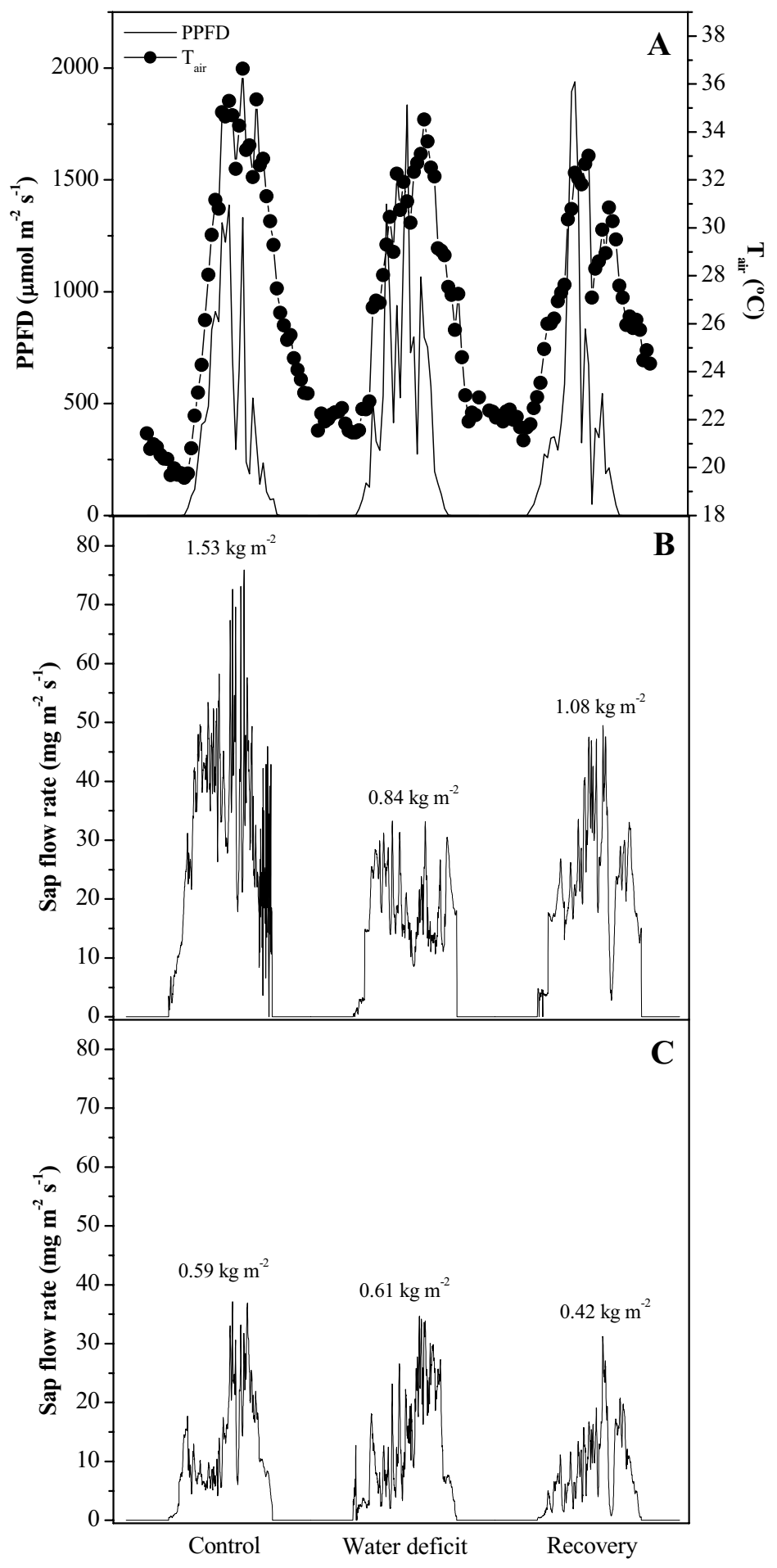

Fig. 1 - Daily changes in photosynthetic photon flux density (PPFD) and air temperature (Tair) (A), and mean sap flow of three seedlings of G. ulmifolia (B) and C. legalis (C) at each experimental condition: control, water deficit, and recovery. Values of daily-integrated sap flow $\left(\mathrm{kg} \mathrm{m}^{-2}\right)$ are shown for each condition. 

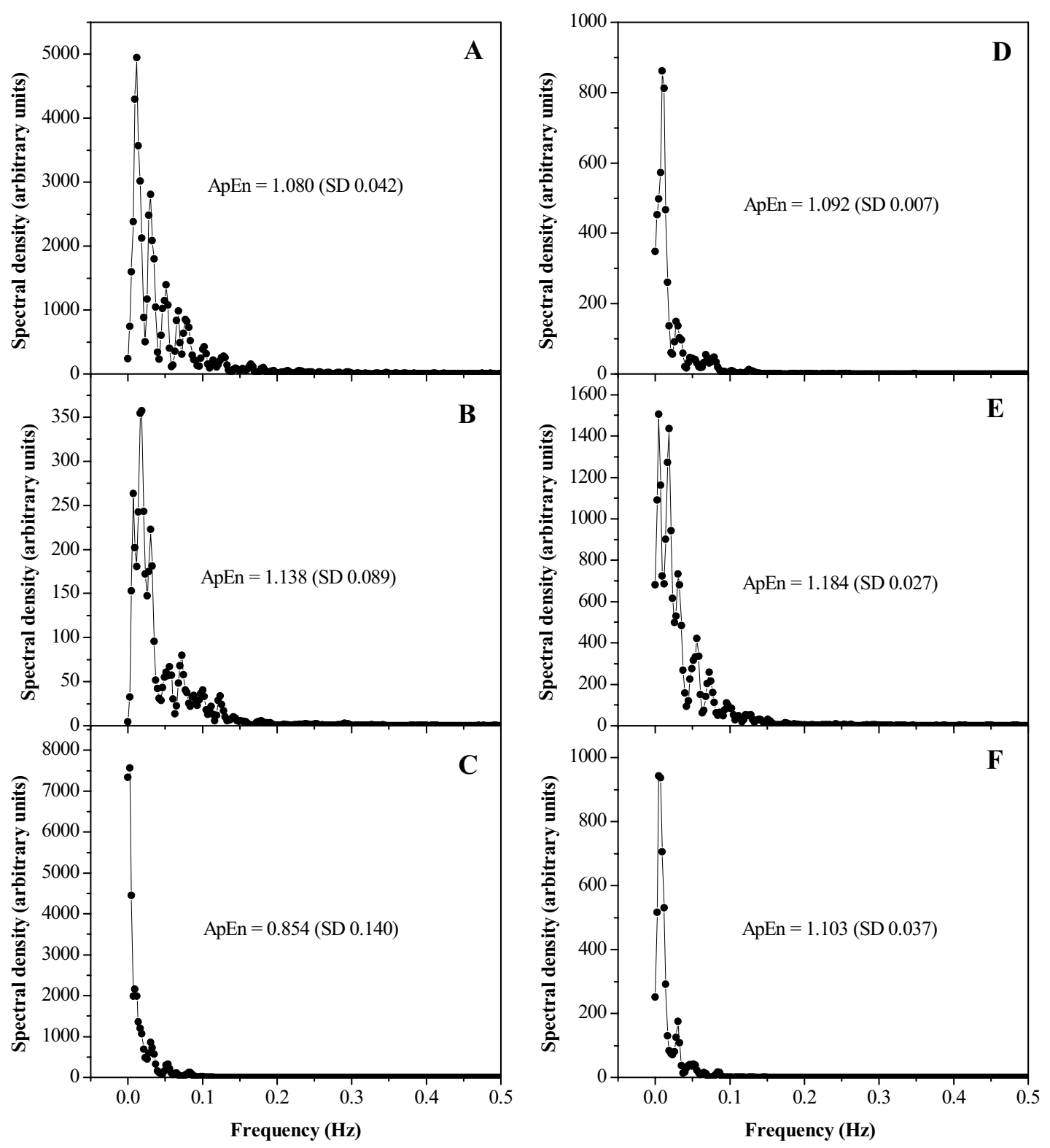

Fig. 2 - Spectral analysis by FFT of sap flow time series of G. ulmifolia (A, B, C) and C. legalis (D, E, F) at control (A, D), water deficit (B, E), and recovery (C, F) conditions. Mean values of Approximate Entropy (ApEn) are shown inside each figure $(n=3$, $\mathrm{SD}=$ standard deviation).

levemente aumentada sob deficiência hídrica. O estudo mostrou que ApEn pode ser usada como um método para detectar pequenas alterações na dinâmica temporal de dados fisiológicos, e revelar alguns padrões de respostas fisiológicas a estímulos ambientais.

Palavras-chave: Entropia Aproximada, complexidade, fluxo de seiva, análise de séries temporais, ecofisiologia tropical, deficiência hídrica.

\section{REFERENCES}

Bruhn J, Ropcke H, Rehberg B, Bouillon T AND Hoeft A. 2000. Electroencephalogram approximate 
entropy correctly classifies the occurrence of burst suppression pattern as increasing anesthetic drug effect. Anesthesiology 93: 981-985.

Chatfield C. 1989. The analysis of time series: an introduction. London: Chapman \& Hall. p. 42-43, 59-60.

Christen JA, Torres J-L and Barrera J. 1998. A statistical feature of genetic sequences. Biom J 40: 855-863.

Fleisher LA, Pincus SM ANd Rosenbaum SH. 1993. Approximate entropy of heart rate as a correlate of postoperative ventricular dysfunction. Anesthesiology 78: 683-692.

Hütt M-Th, RAscher U, Beck F ANd LÜTtGe U. 2002. Period-2 cycles and 2:1 phase locking in biological clock driven by temperature pulses. J Theor Biol 217: 383-390.

Krempaský J, Smrcinová M and Ballo P. 1993. Periodicity and chaos in a photosynthetic system. Photosynth Res 37: 159-164.

LORENZI H. 1992. Árvores brasileiras: manual de identificação e cultivo de plantas arbóreas nativas do Brasil. Nova Odessa: Editora Plantarum Ltda, 352p.

LÜTTGE U AND BECK F. 1992. Endogenous rhythms and chaos in crassulacean acid metabolism. Planta 188: 28-38.

NoBel PS. 1999. Physicochemical and environmental plant physiology. San Diego: Academic Press, 474p.

PINCUS SM. 1991. Approximate entropy as a measure of system complexity. Proc Natl Acad Sci USA 88: 2297-2301.

PINCUS SM. 2000. Irregularity and asynchrony in biologic network signals. Methods Enzymol 321: 49 182.

Pincus SM and Goldberger AL. 1994. Physiological time-series analysis: What does regularity quantify? Am J Physiol 266: H1643-1656.

Pincus SM And Huang WM. 1992. Approximate entropy: statistical properties and applications. Commun Statist - Theory Meth 21: 3061-3077.

Pincus SM AND Singer BH. 1996. Randomness and degrees of irregularity. Proc Natl Acad Sci USA 93: 2083-2088.
Pincus SM AND Singer BH. 1998. A recipe for randomness. Proc Natl Acad Sci USA 95: 10367-10372.

Pincus SM, Cummins TR and Haddad GG. 1993. Heart rate control in normal and aborted SIDS infants. Am J Physiol 264: R638-R646.

Pincus SM, Padmanabhan V, Lemon W, Randolph J AND Midgley AR. 1998. FSH is secreted more irregularly than LH in both human and sheep. J Clin Invest 101: 1318-1324.

Poon C-S AND Barahona M. 2001. Titration of chaos with added noise. Proc Natl Acad Sci USA 98: 71077112 .

Rose MA, Beattie DJ And White JW. 1994. Oscillations of whole-plant transpiration in moonlight rose. J Amer Soc Hort Sci 119: 439-445.

Sakuratani T. 1981. A heat balance method for measuring water flux in the stem of intact plants. J Agric Meteorol 37: 9-17.

Shabala S, Delburgo R and Newman I. 1997. Observations of bifurcation and chaos in plant physiological responses to light. Aust J Plant Physiol 24: 91-96.

Souza GM And Oliveira RF. 2003. Complexity and stability in biological systems. In: D'OtTaviano IML ET AL. (org.), Auto-organização: estudos interdisciplinares, Campinas: CLE/UNICAMP (in press) (in Portuguese).

Souza GM, Oliveira RF and Cardoso VJM. 2004. Temporal dynamics of stomatal conductance of plants under water deficit: can homeostasis be improved by more complex dynamics? Braz Arch Biol Technol (in press).

VAN BAVEl MG. 1999. Dynagage ${ }^{\text {TM }}$ instalation and operation manual. Houston: Dynamax Inc., 82p.

VAN Voris P, O’Neill RV, Emanuel WR and Shugart HH JR. 1980. Functional complexity and ecosystem stability. Ecology 61: 1352-1360.

Williams GP. 1997. Chaos theory tamed. Washington, D.C.: Joseph Henry Press, p. 131-158. 